\title{
THE EFFICIENCY OF Pistacia atlantica GUM FOR INCREASING RESISTANCE OF RAPESEED OIL-HEAT TREATED WOOD TO FUNGAL ATTACKS
}

\author{
Morad Mahmoud Kia ${ }^{1}$, Asghar Tarmian ${ }^{1, \$}$, Ali Naghi Karimi ${ }^{1}$, Hadi Gholamiyan ${ }^{1}$, Ali Abdulkhani ${ }^{1}$, \\ Mohamad Reza Mastri Farahani ${ }^{2}$
}

\begin{abstract}
In this research, we used Pistacia atlantica gum during cooling phase of oil-heat treatment of poplar wood (Populus deltoids) to improve its resistance to the white-rot fungus Trametes versicolor and growth of the mold fungus Penicillium expansum. Thermal modification was carried out using rapeseed oil at $180{ }^{\circ} \mathrm{C}, 200{ }^{\circ} \mathrm{C}$ and $220^{\circ} \mathrm{C}$ for 2 hours and 4 hours. The modified wood specimens were then directly cooled in the oil containing $0 \%, 5 \%$ and $10 \%(\mathrm{w} / \mathrm{w})$ of the gum at $25{ }^{\circ} \mathrm{C}$ for 30 minutes. The chemical constituents of the essential oil extracted with a Clevenger type apparatus were determined by chromatography-mass spectrometry (GC-MS). The amounts of $\alpha$-pinene, $\beta$-pinene and $\alpha$-terpinolene of the essential oil were $60,2 \%, 8,7 \%$ and 3,9 $\%$, respectively. The mold resistance was greatly improved, while the improvement against the decay fungus was only observed for the specimens modified at $180^{\circ} \mathrm{C}$. Our results confirmed that the enhanced fungal resistance was not only due to the presence of monoterpenes in the essential oil, but also to a further reduction in the hygroscopicity of the treated wood.
\end{abstract}

Keywords: Fungal resistance, oil-heat treated wood, Penicillium expansum, Pistacia atlantica, Populus deltoids, Trametes versicolor.

\section{INTRODUCTION}

Natural compounds of plants, such as essential oils, and extractives from very durable wood species, can be used as alternatives to harmful chemical preservatives for biological protection of wood (Pánek et al. 2014, Xie et al. 2017, Fernández-Costas et al. 2017, Zhang et al. 2016, Bahmani and Schmidt 2018). Essential oils are mostly composed of terpenes (e.g. mono-, di- and sesqui-terpenes), which have antimicrobial activity (Dhifi et al. 2016). So far, the potential uses of several essential oils from different parts of plants like Syzygium aromaticum, Betula pendula, Lavandula angustifolia, Origanum vulgare, Acorus calamus, Satureja hortensis, Salvia officinalis, Melaleuca alternifolia, Thymus vulgaris (Pánek et al. 2014), Cymbopogon citratus, Pelargonium graveolens, Cinnamomum zeylanicum, Eugenia caryophyllata (Xie et al. 2017), Eucalyptus camaldulensis, Pinus rigida (Salem et al. 2016), Cedrus atlantica (Fidah et al. 2016), Artemisia monosperma, Cupressus sempervirens, Citrus limon, Thuja occidentalis and Schinus molle, Pelargonium graveolens (Mohareb et al. 2013), Cymbopogon winterianus, Eucalyptus globolus, Foeniculum vulgare, Ilium verum, Juniperus mexicana, Matricaria chamomilla, Melaleuca alternifolia, Melea arachdirachta, Mentha arvensis, Mentha piperita, Oenothera biennis, Trachyspermum copticum (Bahmani and Schmidt 2018) have been investigated for protection of wood against mold and decay fungi.

\footnotetext{
${ }^{1}$ Department of Wood and Paper Science and Technology, Faculty of Natural Resources, University of Tehran, Karaj, Iran. ${ }^{2}$ Department of Wood Engineering and Technology, Gorgan University of Agricultural Sciences and Natural Resources, Gorgan, Iran. •Corresponding author: tarmian@ut.ac.ir Received: 24.04.2019 Accepted: 25.05.2020
} 
Pistacia atlantica is a deciduous tree species which grows from Iranian plateau to North Africa. The exudate gum from the tree trunk which is rich in monoterpene hydrocarbons is used in pharmaceutical and food industries (Barrero et al. 2005, Benhammou et al. 2008). It was historically used by some philosophers such as Abu Ali Sina as a medicine for abdominal pain and stomach ulcers. The gum exudate is obtained by injuring the trunk using a sharp adze at the end of spring. The production process of the gum was described in detail by Ahmed (2017). Antifungal and antibacterial properties of the essential oil extracted from different parts of P. atlantica tree (leaves, fruits and gum) have been reported in numerous previous works (Benhammou et al. 2008, Talibi et al. 2012, Habibi Najafi et al. 2014, Rezaie et al. 2015, Hamelian et al. 2018), but the question is whether the essential oil can improve the resistance to wood-decay fungi. Unlike molds, which generally feed on starch, simple sugars and proteins stored in the ray and axial parenchyma cells of sapwood, the decay fungi consume the cell wall components (i.e. cellulose, hemicellulose and lignin). Sadeghi et al. (2016) found that the gum, fruit and leaves essential oils of Pistacia atlantica subsp. Kurdica had insecticide activities against Tribolium castaneum (Herbst) (Coleoptera: Tenebrionidae) beetle. The insecticidal properties of the essential oils of this plant against Callosobruchus maculatus (Fabricius) (Coloeptera: Bruchidae) was also reported by Pourya et al. (2018).

Oil-heat treatment (OHT) is one of the most environmentally friendly methods of wood modification, which involves the heating of wood in oil at relatively high temperatures (usually $180{ }^{\circ} \mathrm{C}$ to $260^{\circ} \mathrm{C}$ ). Thermal modification is well known to be effective in improving the dimensional stability and decay resistance of wood (Lee et al. 2018). Various vegetable oils with high thermal stability (e.g. linseed, canola, palm, soy and coconut oil) can be used for the modification. The oil provides a fast and uniform heat transfer in wood and prevents its oxidation by formation of a barrier between the wood and oxygen. The characteristics of oil-heat treated wood depend on several factors, such as oil temperature, wood species, period of heating and weight percent gain (Lee et al. 2018). Although oil heat treatment improves the resistance of wood against biodeterioration agents, the modified wood remains susceptible to decay fungi and molds. Therefore, some researchers have recently used several additives with oil to improve the performance of oil-heat treated wood (Lyona et al. 2007, Mohebby et al. 2014). It was found that impregnation of wood with a $1,0 \% \mathrm{w} / \mathrm{w}$ boric acid solution prior to oil treatment reduced the leaching of the preservative, and improved the decay and termite resistance of the wood (Lyona et al. 2007). Mohebby et al. (2014) also improved the physico-mechanical properties of olethermal modified fir wood by using soybean oil combined with maleic anhydride.

This study aimed to improve the resistance of oil-heat treated poplar wood to growth of the mold Penicillium expansum and the white-rot fungus Trametes versicolor by using $P$. atlantica gum during the cooling stage of the thermal modification process. Poplar is a fast-growing species that is widely used for the manufacture of a broad range of forest products. However, modification or preservative treatment is generally required to extend the service life of this non-durable wood.

\section{MATERIALS AND METHODS}

\section{Materials}

A poplar tree species (Populus deltoids L.), growing in an experimental forest (Nowshahr, Mazandaran Province, Iran), belonging to University of Tehran was felled. Then, the sapwood specimens with dimensions required for each test were cut. $P$. atlantica gum with density of $1100 \mathrm{~kg} / \mathrm{m}^{3}$ and $\mathrm{pH}$ of 5 was prepared from Zagros forest located in Kurdistan province of Iran. Rapeseed oil with density of $920 \mathrm{~kg} / \mathrm{m}^{3}$ and dynamic viscosity of $0,078 \mathrm{~Pa}$ s at $20^{\circ} \mathrm{C}$ was used for thermal modification. The oil was purchased from Zeyton Talaei Co. in Qazvin, Iran.

\section{Extraction of essential oil}

In order to determine the type and amount of components in the essential oil of $P$. atlantica, the oil was initially extracted from the gum by hydrodistillation method using a Clevenger type apparatus. For this purpose, $50 \mathrm{~g}$ of gum was heated with distillated water at the boiling temperature of about $100^{\circ} \mathrm{C}$ for 2 hours. The extracted essential oil was subsequently dried over anhydrous sodium sulfate and stored in a dark glass inside a refrigerator at $4{ }^{\circ} \mathrm{C}$ until tested. 


\section{Gas chromatography/mass spectrometry analysis}

Gas chromatography-mass spectrometry (5975C Series GC/MSD system) with column length of $30 \mathrm{~m}$ and inside diameter (id) of $0,25 \mathrm{~mm}$ was used to identify the essential oil components. Helium gas was used as the carrier gas at a flow rate of $1 \mathrm{ml} / \mathrm{min}$. The column temperature ranged from $45^{\circ} \mathrm{C}$ to $250{ }^{\circ} \mathrm{C}$ at $3{ }^{\circ} \mathrm{C} / \mathrm{min}$.

\section{Attenuated total reflectance/Fourier transform infrared (ATR-FTIR) spectroscopy}

The chemical structure of the gum was also determined by Equinox 55 ATR-FTIR spectrometer (Bruker Optics GmbH, Ettlingen, Germany). The spectroscopy was carried out at the wavenumber of $400 \mathrm{~cm}^{-1}$ to 4000 $\mathrm{cm}^{-1}$ using 64 scans at a resolution of $4 \mathrm{~cm}^{-1}$. The obtained spectra were baseline corrected by the concave rubber band method and max-min normalized.

\section{Thermal modification}

Prior to thermal modification, the wood samples were conditioned at $20{ }^{\circ} \mathrm{C}$ and relative humidity (RH) of $65 \%$ to $12 \%$ moisture content (MC). Then, the specimens were immersed in a cylinder containing rapeseed oil. Thermal modification was carried out at $180{ }^{\circ} \mathrm{C}, 200{ }^{\circ} \mathrm{C}$ and $220^{\circ} \mathrm{C}$ for 2 hours and 4 hours. The cooling stage of the process was done in the rapeseed oil containing P. atlantica gum at concentrations of $5 \%$ and 10 $\%(\mathrm{w} / \mathrm{w})$ at $25{ }^{\circ} \mathrm{C}$ for 30 minutes. After cooling, the temperature of the solution varied from $50{ }^{\circ} \mathrm{C}$ to $60{ }^{\circ} \mathrm{C}$. The modified samples were dried at $103{ }^{\circ} \mathrm{C} \pm 2{ }^{\circ} \mathrm{C}$ for 24 hours and weighed to determine the weight percent gain (WPG).

\section{X-ray scanning}

The vertical density profile of the modified wood specimens was measured using a commercial X-ray scanner (Siempelkamp's Sicoscan, Germany) to determine the uniformity of the modification process. The specimens were prepared with dimensions of $50 \mathrm{~mm} \times 50 \mathrm{~mm} \times 50 \mathrm{~mm}$ according to the instruction manual of the device. The measurements were performed by scanning across the thickness in the middle of the specimens.

\section{Moisture exclusion efficiency}

The oven-dried samples were placed in a conditioning room at $20{ }^{\circ} \mathrm{C}$ and $65 \% \mathrm{RH}$ for 3 weeks to determine the moisture exclusion efficiency (MEE) of the modified woods. The efficiency was determined by Equation 1:

$$
M E E=\left(\frac{E_{u}-E_{m}}{E_{u}}\right) \times 100
$$

Where $\mathrm{E}_{\mathrm{u}}$ and $\mathrm{E}_{\mathrm{m}}$ are the equilibrium moisture content (EMC) of the control and modified woods.

\section{Decay test}

The resistance of the wood samples to the white-rot fungus Trametes versicolor (strain: CTB 863A) was evaluated. The fungal strain was obtained from Wood Preservation Laboratory, Research Unit, BioWooEB, CIRAD, Montpellier, France. Wood blocks with dimensions of $15 \mathrm{~mm} \times 25 \mathrm{~mm} \times 50 \mathrm{~mm}(\mathrm{~L} \times \mathrm{R} \times \mathrm{T})$ were prepared according to European standard test method CEN EN113 (1996). A uniform culture medium (malt extract agar, MEA) was prepared by adding $45 \mathrm{~g}$ of malt agar to $1000 \mathrm{ml}$ of distilled water, followed by heating the solution for 15 minutes. Then, the medium was sterilized inside a steam autoclave at $120^{\circ} \mathrm{C}$ for 20 minutes. Cubic glass containers with metal lids were used for fungal cultivation. Each container was filled with $70 \mathrm{ml}$ of $4,8 \%(\mathrm{w} / \mathrm{v})$ malt agar solution. A $20-\mathrm{mm}$ diameter hole was made on the glass lid and compressed cotton was placed inside the hole for the air exchange. One modified sample and one unmodified sample were placed inside each container. A plastic mesh was used to prevent the direct contact of the wood samples with the medium. Five replicates were used for each treatment. The specimens were incubated at $22{ }^{\circ} \mathrm{C}$ and $75 \% \mathrm{RH}$ for 16 weeks. After this period, they were removed from incubator, cleaned from the surface fungal mycelium and 
dried for 24 hours in an oven at $103 \pm 2{ }^{\circ} \mathrm{C}$ for 24 hours and the weight loss were finally calculated.

\section{Mold resistance test}

Wood blocks with dimensions of $7 \mathrm{~mm} \times 20 \mathrm{~mm} \times 70 \mathrm{~mm}(\mathrm{~T} \times \mathrm{R} \times \mathrm{L})$ were cut according to the ASTM D4445-91 (1996). Control samples were also prepared from freshly-cut boards with moisture content of about $60 \%$. The strains of Penicillium expansum was provided from Department of Plant Protection at University of Tehran. The wood samples were sterilized in an autoclave at $120^{\circ} \mathrm{C}$ for 20 minutes. Mold spore suspension was prepared by adding $10 \mathrm{ml}$ of distillated water to petri dishes, containing mold spores. Eight filter papers sprayed with the distilled water were placed into each petri dish. Glass tubes with diameter of $3 \mathrm{~mm}$ were put under the wood specimens to prevent the direct contact of the specimens with the wet filter papers. The specimens were sprayed with $1 \mathrm{ml}$ of mold spore suspension and incubated at $25{ }^{\circ} \mathrm{C}$ and $70 \% \mathrm{RH}$ for 4 weeks. After this period, the mold coverage was visually determined on a scale of $0-5$ and reported as 0 (free of mold growth), 1 ( $1 \%$ to $5 \%), 2$ (6\% to $25 \%), 3$ (26\% to $50 \%), 4(51 \%$ to $75 \%$ ) and 5 with heavy mold growth (mold coverage of $76 \%$ to $100 \%$ ). Data analysis was done using SPSS software and the mean of data was compared using Duncan test at $5 \%$ level.

\section{RESULTS AND DISCUSSION}

\section{Chemical structure of $P$. atlantica essential oil}

The chemical components of $P$. atlantica essential oil are shown in Table $1 \alpha$-pinene, $\beta$-pinene and $\alpha$-terpinolene were the most constituents of the oil with amount of $60,15 \%, 8,68 \%$ and 3,93 \%, respectively. The type and amount of chemical compounds of P. atlantica essential oil determined in this study were slightly different with those reported in some previous researches (Alma et al. 2004, Barrero et al. 2005, Salimi et al. 2011). Barrero et al. (2005) identified the $\alpha$-pinene and $\beta$-pinene as the main components of the essential oil with amount of $42,9 \%$ and $13,2 \%$, respectively. These differences may be due to variation in tree species, sampling time, and growth conditions (Alma et al. 2004).

Table 1: Chemical composition of P. atlantica gum.

\begin{tabular}{|c|c|c|c|c|}
\hline Chemical name & Molecular weight & Formula & CAS number & Percentage \\
\hline$\alpha$-pinene & 136,13 & $\mathrm{C}_{10} \mathrm{H}_{16}$ & $8-56-000080$ & 60,15 \\
\hline$\beta$-pinene & 136,13 & $\mathrm{C}_{10} \mathrm{H}_{17}$ & $3-91-000127$ & 8,68 \\
\hline$\alpha$-terpinolene & 136,13 & $\mathrm{C}_{10} \mathrm{H}_{16}$ & $9-62-000586$ & 3,94 \\
\hline Trans-verbenol & 152,12 & $\mathrm{C}_{10} \mathrm{H}_{16} \mathrm{O}$ & $3-09-001820$ & 3,03 \\
\hline Del- limonene & 163,13 & $\mathrm{C}_{10} \mathrm{H}_{16}$ & $3-86-000138$ & 2,67 \\
\hline P-mentha-1,5-dien-8-ol & 152,12 & $\mathrm{C}_{10} \mathrm{H}_{16} \mathrm{O}$ & $0-20-001686$ & 2,57 \\
\hline Pinocarveol, trans & 152,12 & $\mathrm{C}_{10} \mathrm{H}_{16} \mathrm{O}$ & $5-61-000547$ & 2,49 \\
\hline$\alpha$-terpineol & 154,14 & $\mathrm{C}_{10} \mathrm{H}_{18} \mathrm{O}$ & $5-55-000098$ & 2,29 \\
\hline Camphene & 136,13 & $\mathrm{C}_{10} \mathrm{H}_{16}$ & $5-92-000079$ & 1,99 \\
\hline$\beta$-myrcene & 136,12 & $\mathrm{C}_{10} \mathrm{H}_{16}$ & $3-35-000123$ & 1,70 \\
\hline$\alpha$-bornyl acetate & 196,15 & $\mathrm{C}_{12} \mathrm{H}_{20} \mathrm{O}_{2}$ & $8-61-005655$ & 1,65 \\
\hline $1,8-$ cineole & 154,14 & $\mathrm{C}_{10} \mathrm{H}_{18} \mathrm{O}$ & $6-82-000470$ & 1,57 \\
\hline Camphor aldehyde & 152,12 & $\mathrm{C}_{10} \mathrm{H}_{16} \mathrm{O}$ & $1-03-026882$ & 1,32 \\
\hline Delta-3-carene & 136,13 & $\mathrm{C}_{10} \mathrm{H}_{16}$ & $9-78-013466$ & 1,31 \\
\hline Hexane & 86,11 & $\mathrm{C}_{6} \mathrm{H}_{14}$ & $3-54-000110$ & 1,24 \\
\hline Pi- mirsen & 134,11 & $\mathrm{C}_{10} \mathrm{H}_{14}$ & $6-87-000099$ & 1,04 \\
\hline Mirtenol & 152,12 & $\mathrm{C}_{10} \mathrm{H}_{16} \mathrm{O}$ & $4-00-000515$ & 0,75 \\
\hline Trans-(+)carveol & 152,12 & $\mathrm{C}_{10} \mathrm{H}_{16} \mathrm{O}$ & $5-07-001197$ & 0,66 \\
\hline 2-pinen-4-one & 150,10 & $\mathrm{C}_{10} \mathrm{H}_{14} \mathrm{O}$ & $9-57-000080$ & 0,55 \\
\hline Exo-2-hydroxycineole & 212,14 & $\mathrm{C}_{10} \mathrm{H}_{20} \mathrm{O}_{3}$ & $2-95-057709$ & 0,41 \\
\hline & & & & \\
\hline
\end{tabular}




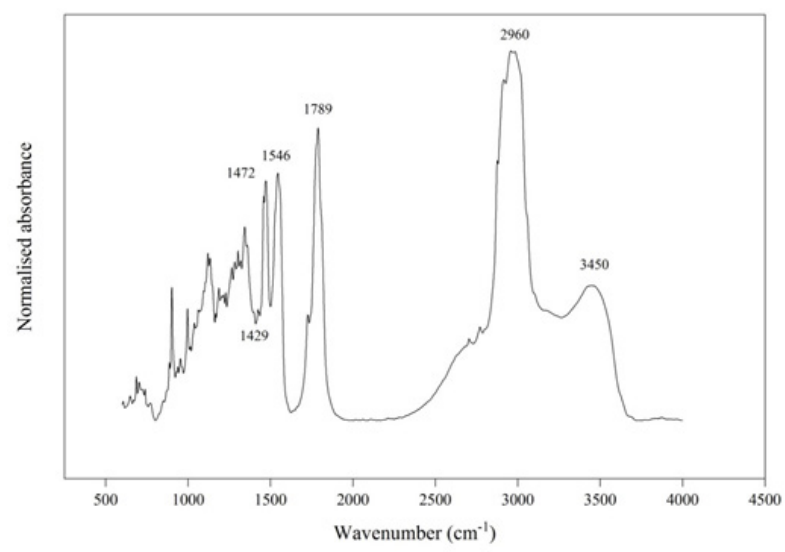

Figure 1: ATR-FTIR spectrum of $P$. atlantica gum.

The FTIR spectrum of the gum is given in Figure 1. The peaks at wavenumbers of $3450 \mathrm{~cm}^{-1}, 2960 \mathrm{~cm}^{-1}$ and $1789 \mathrm{~cm}^{-1}$ are related to the stretching vibration of $\mathrm{O}-\mathrm{H}, \mathrm{C}-\mathrm{H}$, and $\mathrm{C}=\mathrm{O}$, respectively. The absorption bands at wavenumbers of $1429 \mathrm{~cm}^{-1}$ and $1472 \mathrm{~cm}^{-1}$ are due to vibration of $\mathrm{C}-\mathrm{H}$ group. The peak occurred in the wavenumber of $1546 \mathrm{~cm}^{-1}$ is also caused by vibration of $\mathrm{N}-\mathrm{H}$ and $\mathrm{C}=\mathrm{N}$.

\section{Weight percent gain and moisture exclusion efficiency}

The oil-heat treatment yielded a WPG in the range of $60,7 \%$ to $77,6 \%$ (Figure 2 ). The WPG after thermal modification in oil was previously reported to be in the range of $50 \%$ to $90 \%$, depending on the process variables (time and temperature) and wood species (Sailer et al. 2000, Lee et al. 2018). The weight of wood is normally reduced due to thermal degradation of the cell wall polymers; however, the amount of oil uptake during thermal modification with oil is much more than the weight loss caused by the thermal degradation, resulting in the weight gain. The WPG increased by using $P$. atlantica gum, which was directly proportional to its concentration. In agreement with previous works (Lee et al. 2018), the WPG decreased by increasing the modification temperature from $180{ }^{\circ} \mathrm{C}$ to $220^{\circ} \mathrm{C}$ when the cooling stage was carried out in the oil without $P$. atlantica gum. This can be due to further destruction of the wood cell wall compounds at higher temperatures. In contrast, the WPG was greater at higher temperatures when the specimens were cooled in the oil containing $5 \%$. atlantica gum. It is believed that the oil is significantly absorbed during the cooling stage of the oil-heat treatment process due to the pressure gradient (Lee et al. 2018).

A uniform pattern of density profile for the modified wood specimens (Figure 3) indicates a roughly homogeneous thermal modification and oil uptake through the specimen thickness. As expected, thermal modification reduced the EMC of wood samples (Figure 4). The moisture exclusion efficiency is usually attributed to degradation of the cell wall polymers, reduction in the hydroxyl $(\mathrm{OH})$ accessibility, polycondensation reactions in the lignin, and formation of thermal degradation products which reduce the microporosity of the cell walls (Esteves and Pereira 2009). The efficiency was also improved by using P. atlantica gum. 


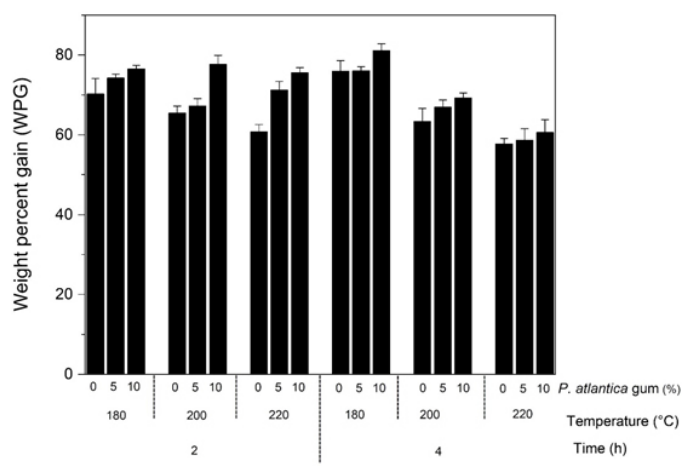

Figure 2: Weight percent gain (WPG) of the poplar wood samples after heat treatment with oil under different treatment conditions.

Means with similar letters are not statistically significantly different $(\alpha=5 \%)$ based on Duncan's multiple range test.

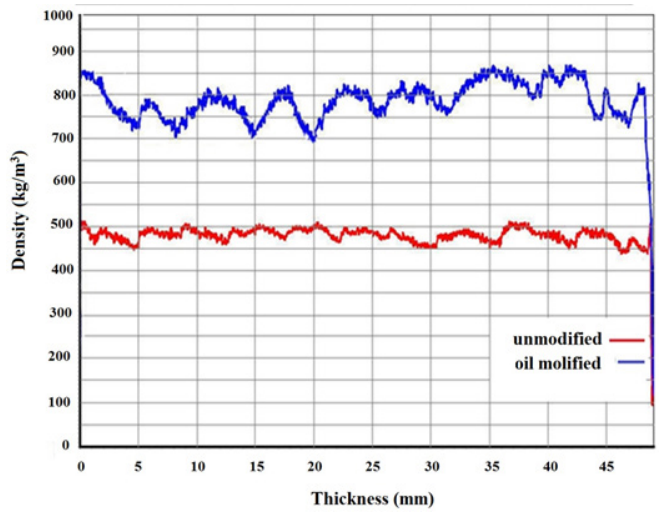

Figure 3: Density profile across the thickness of the control (unmodified) and oil-heat treated poplar wood (treatment condition: $200{ }^{\circ} \mathrm{C}, 2 \mathrm{~h}$ ).

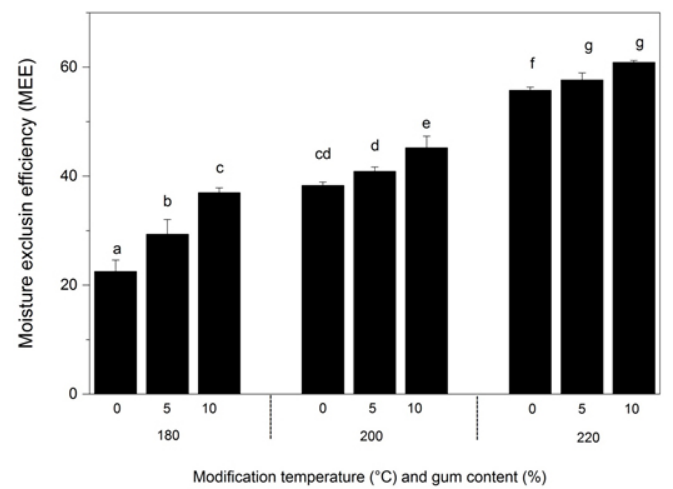

Figure 4: Moisture exclusion efficiency of the poplar wood specimens modified at different temperatures and P. atlantica gum contents for 2 hours.

Means with similar letters are not statistically significantly different $(\alpha=5 \%)$ based on Duncan's multiple range test. 


\section{Fungal resistance}

Results showed that resistance of the wood samples to Trametes versicolor was improved by oil heat treatment (Figure 5). The improvement in the fungal resistance of wood by thermal modification can be explained by the bulking effects, reduction in the accessible hydroxyl $(\mathrm{OH})$ groups and moisture content (Esteves and Pereira 2009, Hill 2006, Thybring 2013). Various toxic extractives, such as phenolic compounds are formed due to thermal modification, which can reduce the fungal growth until they remain in the modified wood. Diffusion of low molecular weight degradative agents within the cell walls is the most likely mechanism responsible for wood decay during initial biodegradation (Schmidt 2006). The presence of water in the cell walls is essential for such a diffusion process. A reduction in the cell wall moisture content caused by thermal modification limits the diffusion rate (Esteves and Pereira 2009, Thybring 2013). Changes in the crystallinity of wood due to thermal modification can be another factor in controlling the natural durability of the modified wood (Esteves and Pereira 2009). In agreement with previous findings (Esteves and Pereira 2009, Calonego et al. 2010, Lee et al. 2018), our results showed that the decay resistance was improved by increasing the temperature of thermal modification from $180^{\circ} \mathrm{C}$ to $220^{\circ} \mathrm{C}$. Hakkou et al. (2006) also reported a strong correlation between the temperature of thermal modification and fungal durability of heat-treated beech wood to T. versicolor. We found no improvement in the decay resistance by increasing the modification time. The decay resistance of wood specimens modified at $180^{\circ} \mathrm{C}$ was slightly improved by using $P$. atlantica gum. The improving effect can be due to monoterpenes of the gum that have antifungal activity (Mohareb et al. 2013). However, at higher modification temperatures, i.e. $200{ }^{\circ} \mathrm{C}$ and $220^{\circ} \mathrm{C}$, the use of $P$. atlantica gum was not effective in improving the decay resistance. Bahmani and Schmidt (2018) showed the inhibition of surface colonization of Fagus orientalis wood samples by the oils from Cybopogon winterianus, Lavandula angustifolia, Thymus vulgaris and Trachsperum copticum.

Mold resistance of the specimens was also improved after oil heat treatment. The improvement was more pronounced at higher temperatures (Figure 6). This is mainly due to reduction in the hygroscopicity of wood after heat treatment (Ahmed et al. 2017). On the other hand, similar to what was observed with the decay resistance, the growth of mold was not significantly affected by increasing the heat treatment duration from 2 hours to 4 hours. According to the classification system of mold attacks (Waals et al. 2003), all oil heat-treated specimens were in the same class of the mold growth. The control specimens with $76 \%$ to $100 \%$ mold coverage were in class 5 , while the modified specimens with $51 \%$ to $75 \%$ mold coverage were in class 4 .

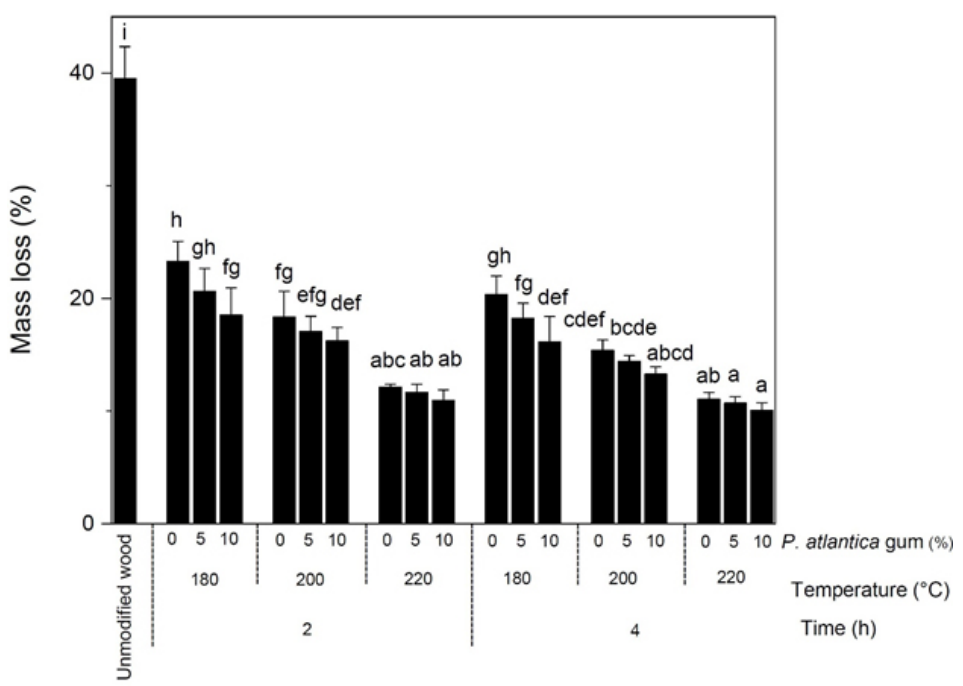

Figure 5: Mass loss of the control and oil heat-treated poplar wood specimens due to degradation by Trametes versicolor.

Means with similar letters are not statistically significantly different $(\alpha=5 \%)$ based on Duncan's multiple range test.

Although the oil heat treatment improved the mold resistance, the modified woods were not completely safe from the mold attack. Unlike decay fungi that feed on the cell wall compounds, molds feed on the stored starches, sugars and proteins, and thus the cell wall alteration caused by thermal modification has little influence on the mold control. Thus, it is recommended to use mold-resistant coatings for protection of ther- 
mally modified wood against molds. Boonstra et al. (2007) also found that the heat-treated radiata pine and Norway spruce were susceptible to mold growth due to formation of some thermal degradation products like surges. The addition of $P$. atlantica gum to the rapeseed oil significantly reduced the mold coverage. All wood specimens treated by using $P$. atlantica gum with mold coverage of $26 \%$ to $50 \%$ were in class 3 . However, the gum could not completely prevent the mold growth. The enhanced mold resistance is due to the antimicrobial properties of the gum, along with the improved moisture exclusion efficiency of the modified wood. Antifungal efficiency of $P$. atlantica essential oil against Penicillium italicum (Talibi et al. 2012), Aspergillus niger, Aspergillus flavus, Aspergillus fumigatus (Shialy et al. 2015), Rhizopus stolonifer, Trichoderma sp and Fusarium sp (Benhammou et al. 2008) was also previously reported. Bahmani and Schmidt (2018) showed complete growth inhibition of $A$. niger and P. commune on Pinus taeda wood samples by the oils from $C y$ bopogon winterianus, Lavandula angustifolia and Thymus vulgaris and additionally by Trachsperum copticum oil on Fagus orientalis samples.

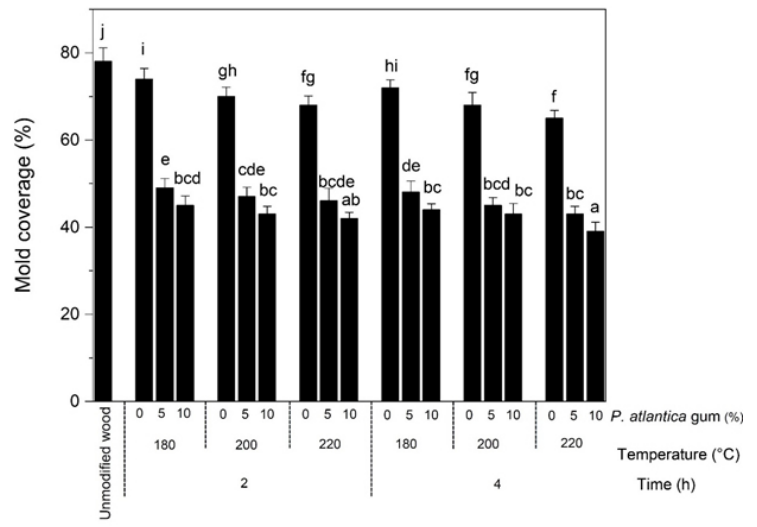

Figure 6: Mold resistance of the control and oil heat-treated poplar wood.

Means with similar letters are not statistically significantly different $(\alpha=5 \%)$ based on Duncan's multiple range test.

\section{CONCLUSIONS}

We found that the $P$. atlantica gum had more pronounced effect on the mold growth of the oil-heat treated wood than the decay resistance. The improvement can be due to the presence of monoterpenes such as $\alpha$-pinene, $\beta$-pinene and $\alpha$-terpinolene in the $P$. atlantica essential oil as well as a further increase in the moisture exclusion efficiency of the treated wood. The results of this study also showed that increasing the heat-treatment temperature was more successful than increasing the heat-treatment time to improve the resistance of the oil-heat treated wood to the fungal attacks. Considering the high amount of $\alpha$-pinene and $\beta$-pinene in the $P$. atlantica essential oil, study on its efficiency for preservation of wood against wood-destroying insects is recommended.

\section{REFERENCES}

Ahmed, H.M. 2017. Traditional uses of Kurdish medicinal plant Pistacia atlantica subsp. kurdica Zohary in Ranya, Southern Kurdistan. Genet Resour Crop Ev 64(6): 1473-1484. https://doi.org/10.1007/s10722-017-0522-4

Ahmed, S.A.; Morén, T.; Sehlstedt-Persson, M.; Blom, A. 2017. Effect of oil impregnation on water repellency, dimensional stability and mold susceptibility of thermally modified European aspen and downy birch wood. J Wood Sci 63(1): 74-82. https://doi.org/10.1007/s10086-016-1595-y

Alma, M.H.; Nitz, S.; Kollmannsberger, H.; Digrak, M.; Efe, F.T.; Yilmaz, N. 2004. Chemical composition and antimicrobial activity of the essential oils from the gum of Turkish pistachio (Pistacia vera $L$.). $J$ Agr Food Chem 52(12): 3911-3914. https://doi.org/10.1021/jf040014e

ASTM. 1996. Standard test method for fungicides for controlling sapstain and mold on unseasoned lumber (laboratory method). ASTM. D4445-91e1. 1996. ASTM International: West Conshohocken, PA. 
https://doi.org/10.1520/D4445-91R96E01

Bahmani, M.; Schmidt, O. 2018. Plant essential oils for environment-friendly protection of wood objects against fungi. Maderas-Cienc Tecnol 20(3): 325-332. http://dx.doi.org/10.4067/S0718-221X2018005003301

Barrero, A.F.; Herrador, M.M.; Arteaga, J.F.; Akssira, M.; Mellouki, F.; Belgarrabe, A. 2005. Chemical Composition of the Essential Oils of Pistacia atlantica Desf. J Essent Oil Res 17(1): 52-54. https://doi.org/10.1080/10412905.2005.9698828

Benhammou, N.; Bekkara, F.A.; Panovska, T.K. 2008. Antioxidant and antimicrobial activities of the Pistacia lentiscus and Pistacia atlantica extracts. Afr J Pharm Pharmaco 2(2): 22-28. https://academicjournals.org/journal/AJPP/article-full-text-pdf/86CD3DD32024

Boonstra, M.J.; Van Acker, J.; Kegel, E.; Stevens, M. 2007. Optimisation of a two-stage heat treatment process: durability aspects. Wood Sci Technol 41(1): 31-57. https://doi.org/10.1007/s00226-006-0087-4

CEN. 1996. Wood preservatives-method of test for determining the protective effectiveness against wood destroying basidiomycetes. Determination of the toxic values. CEN. EN 113. 1996. Brussels, Belgium.

Calonego, F.W.; Severo, E.T.D.; Furtado, E.L. 2010. Decay resistance of thermally-modified Eucalyptus grandis wood at $140^{\circ} \mathrm{C}, 160^{\circ} \mathrm{C}, 180^{\circ} \mathrm{C}, 200^{\circ} \mathrm{C}$ and $220^{\circ} \mathrm{C}$. Bioresour Technol 101(23): 9391-9394. https://doi.org/10.1016/j.biortech.2010.06.119

Dhifi, W.; Bellili, S.; Jazi, S.; Bahloul, N.; Mnif, W. 2016. Essential oils' chemical characterization and investigation of some biological activities: a critical review. Medicines 3(4): 25-31. https://doi.org/10.3390/medicines3040025

Esteves, M.; Pereira, H.M. 2009. Wood modification by heat treatment: a review. Bioresources 4(1): 370-404.

Fernández-Costas, C.; Palanti, S.; Charpentier, J.P.; Sanromán, M.A.; Moldes, D. 2017. A Sustainable Treatment for Wood Preservation: Enzymatic Grafting of Wood Extractives. Acs Sustain Chem Eng 5(9): 7557-7567. https://doi.org/10.1021/acssuschemeng.7b00714

Fidah, A.; Salhi, N.; Rahouti, M.; Kabouchi, B.; Ziani, M.; Aberchane, M.; Famiri, A. 2016. Natural durability of Cedrus atlantica wood related to the bioactivity of its essential oil against wood decaying fungi. Maderas-Cienc Tecnol 18(4): 567-576. http://dx.doi.org/10.4067/S0718-221X2016005000049

Habibi Najafi, M.B.; Hajimohamadi Farimani, R.; Tavakoli, J.; Madayeni, S. 2014. GC-MS Analysis and Antimicrobial Activity of the Essential Oil of Trunk Exudates of Pistacia atlantica var. mutica. Chem Nat Compd 50(2): 376-378. https://doi.org/10.1007/s10600-014-0959-z

Hakkou, M.; Pétrissans, M.; Gérardin, P.; Zoulalian, A. 2006. Investigations of the reasons for fungal durability of heat-treated beech wood. Polym Degrad Stab 91(2): 393-397. https://doi.org/10.1016/j.polymdegradstab.2005.04.042

Hamelian, M.; Hemmati, S.; Varmira, K.; Veisi, H. 2018. Green synthesis, antibacterial, antioxidant and cytotoxic effect of gold nanoparticles using Pistacia Atlantica extract. J Taiwan Inst Chem E 93: 21-30. https://doi.org/10.1016/j.jtice.2018.07.018

Hill, C.A.S. 2006. Wood modification: chemical, thermal and other processes. John Wiley \& Sons Ltd: Chichester, West Sussex, England.

Lee, S.H.; Ashaari, Z.; Lum, W.C.; Halip, J.A.; Ang, A.F.; Tan, L.P.; Chin, K.L.; Tahir, P.M. 2018. Thermal treatment of wood using vegetable oils: A review. Constr Build Mater 181: 408-419. https://doi.org/10.1016/j.conbuildmat.2018.06.058

Lyon, F.; Thevenon, M.F.; Hwang, W.J.; Imamura, Y.; Gril, J.; Pizzi, A. 2007. Effect of an oil heat treatment on the leachability and biological resistance of boric acid impregnated wood. Ann Forest Sci 64(6): 673-678. http://dx.doi.org/10.1051/forest:2007046 
Mohareb, A.S.; Badawy, M.E.; Abdelgaleil, S.A. 2013. Antifungal activity of essential oils isolated from Egyptian plants against wood decay fungi. J Wood Sci 59(6): 499-505. https://doi.org/10.1007/s10086-013-1361-3

Mohebby, B.; Kevily, H.; Kazemi-Najafi, S. 2014. Oleothermal modification of fir wood with a combination of soybean oil and maleic anhydride and its effects on physico-mechanical properties of treated wood. Wood Sci Technol 48(4): 797-809. https://doi.org/10.1007/s00226-014-0640-5

Pourya, M.; Sadeghi, A.; Ghobari, H.; Clauvis Nji Tizi Taning, C.N.T.; Smagghe, G. 2018. Bioactivity of Pistacia atlantica desf. Subsp. Kurdica (Zohary) Rech. F. and Pistacia khinjuk stocks essential oils against Callosobruchus maculatus (F, 1775) (Coloeptera: Bruchidae) under laboratory conditions. J Stored Prod Res 77: 96-105. https://doi.org/10.1016/j.jspr.2018.03.007

Pánek, M.; Reinprecht, L.; Hulla, M. 2014. Ten essential oils for beech wood protection-efficacy against wood-destroying fungi and moulds, and effect on wood discoloration. Bioresources 9(3): 5588-5603.

Rezaie, R.; Farhoosh, R.; Sharif, A.; Asili, J.; Iranshahi, M. 2015. Chemical composition, antioxidant and antibacterial properties of Bene (Pistacia atlantica subsp. mutica) hull essential oil. J Food Sci Technol 52(10): 6784-6790. https://doi.org/10.1007/s13197-015-1789-0

Sadeghi, A.; Pourya, M.; Smagghe, G. 2016. Insecticidal activity and composition of essential oils from Pistacia atlantica subsp. kurdica against the model and stored product pest beetle Tribolium castaneum. Phytoparasitica 44(5): 601-607. https://doi.org/10.1007/s12600-016-0551-0

Sailer, M.; Rapp, A.O.; Leithoff, H. 2000. Improved resistance of Scots pine and spruce by application of an oil-heat treatment. In Proceedings IRG Annual Meeting, IRG/WP 00-40162. The International Research Group on Wood Protection: Kona, Hawaii, USA.

Salem, N.Z.M.; Zidan, Y.E.; Mansour, M.M.A.; El Hadidi, N.M.N.; Abo Elgat, W.A.A. 2016. Antifungal activities of two essential oils used in the treatment of three commercial wood deteriorated by five common mold fungi. Int Biodeter Biodegr 106: 88-96. https://doi.org/10.1016/j.ibiod.2015.10.010

Salimi, S.; Shafaghat, A.; Sahebalzamani, H.; Alizadeh, M.M.; Rech, F. 2011. $\alpha$-Pinene from Pistacia atlantica Desf. Subsp. Kurdica (Zohary) Rech. F. Der Chemica Sinica 2(3): 1-3. https://www.cabdirect.org/cabdirect/abstract/20113332675

Schmidt, O. 2006. Wood and tree fungi. Springer-Verlag Berlin Heidelberg. https://doi.org/10.1007/3-540-32139-X

Shialy, Z.; Zarrin, M.; Sadeghi Nejad, M.; Yusef Naanaie, S. 2015. In vitro antifungal properties of Pistacia atlantica and olive extracts on different fungal species. Current Medical Mycology 1(4): 40-45. https://www.ncbi.nlm.nih.gov/pmc/articles/PMC5490281/

Talibi, I.; Askarne, L.; Boubaker, H.; Boudyach, E.H.; Msanda, F.; Saadi, B.; Ait Ben Aoumar, A. 2012. Antifungal activity of some Moroccan plants against Geotrichum candidum, the causal agent of postharvest citrus sour rot. Crop Protection 35: 41-46. https://doi.org/10.1016/j.cropro.2011.12.016

Thybring, E.E. 2013. The decay resistance of modified wood influenced by moisture exclusion and swelling reduction. Int Biodeter Biodegr 82: 87-95. https://doi.org/10.1016/j.ibiod.2013.02.004

Waals, J.W.; Chittenden, C.; Kreber, B. 2003. Effect of bioextracts on colonization of radiata pine sapwood by three sapstain fungi. In Proceedings IRG Annual Meeting, IRG/WP 03-10485. The International Research Group on Wood Protection: Brisbane, Queensland, Australia.

Xie, Y.; Wang, Z.; Huang, Q.; Zhang, D. 2017. Antifungal activity of several essential oils and major components against wood-rot fungi. Industrial Crops and Products108: 278-285. https://doi.org/10.1016/j.indcrop.2017.06.041

Zhang, Z.; Yang, T.; Mi, N.; Wang, Y.; li, G.; Wang, L.; Xie, Y. 2016. Antifungal activity of monoterpenes against wood white-rot fungi. Int Biodeter Biodegr 106: 157-160. https://doi.org/10.1016/j.ibiod.2015.10.018 